\title{
At-Taqaddum
}

Vol. 11 No. 1 (2019) pp 61-94

DOI: http://dx.doi.org/10.21580/at.v1li1.3764

\section{DISPARITAS SIKAP PEMAAFAN DI KALANGAN MAHASISWA}

\author{
Moh Khasan \\ UIN Walisongo Semarang \\ Email: moh_khasan@walisongo.ac.id
}

\begin{abstract}
This study aims to determine: 1) the influence of the study program on forgiveness, 2) the influence of gender on forgiveness, 3) the background of the study program and gender interactively on forgiveness. The population of this study was the Syari'ah and Law Faculty students at UIN Walisongo Semarang. The sample in this study was taken by cluster random sampling. The number of selected samples is 81 people. Data collection is done by questionnaire technique. Data analysis using the mean difference test (t-test) and Two Path V ariant Analysis. So in this study, forgiveness $(Y)$ as dependent variable will be viewed from the background of the study program (X1) and gender (X2) as criteria. The results showed that: 1) Students of the Jinayah-Siyasah study program tended to have higher levels of forgiveness than students of Abwal alSyakhsiyyah and Muamalah study programs. The calculation of the $F$ value at the 5 percent significance level shows $F=34,051 \geq 3,119=F(a=0.05: 2,75) ; 2)$ Male students tend to have a higher level of forgiveness than female students. The calculation of the $F$ value at the 5 percent significance level shows $F=45,342 \geq$ $3,968=F(a=0.05: 1,75) ; 3)$ Interactively, the background of the study program and gender does not affect the level of student forgiveness. The result of the calculation of the $F$ value at the 5 percent significance level shows $F=-12.530<3.119=F$ (a $=0.05: 1,75)$. Forgiveness is also one solution to various problems and conflicts between humans, so that it can restore barmony between them.
\end{abstract}

Keywords: Forgiveness, study program, gender, psychology

\begin{abstract}
Abstrak
Penelitian ini bertujuan untuk mengetahui: 1) Pengaruh latar belakang program studi terhadap sikap pemaafan, 2) Pengaruh jenis kelamin Moh. Khasan, Disparitas Sikap ...


terhadap sikap pemaafan, 3) Pengaruh latar belakang program studi dan jenis kelamin secara interaktif terhadap sikap pemaafan. Populasi penelitian ini adalah mahasiswa Fakultas Syariah UIN Walisongo Semarang. Sampel dalam penelitian ini diambil secara cluster random sampling. Jumlah sampel terpilih sebanyak 81 orang. Pengumpulan data dilakukan dengan teknik kuesioner. Analisis data menggunakan uji beda mean (t-test) dan Analisis Varian Dua Jalur. Jadi dalam penelitian ini, sikap pemaafan $(\mathrm{Y})$ variabel dependen akan ditinjau dari latar belakang program studi (X1) dan jenis kelamin (X2) sebagai kriterium. Hasil penelitian menunjukkan bahwa: 1) Mahasiswa program studi JinayahSiyasah cenderung memiliki tingkat sikap pemaafan lebih tinggi dibanding mahasiswa program studi Ahwal al-Syakhsiyyah dan Muamalah. Hasil perhitungan nilai $\mathrm{F}$ pada taraf signifikansi 5 persen menunjukkan $\mathrm{F}=34,051 \geq 3,119=\mathrm{F}(\alpha=0,05: 2,75) ; 2)$ Mahasiswa laki-laki cenderung memiliki tingkat sikap pemaafan lebih tinggi dari pada mahasiswa perempuan. Hasil perhitungan nilai $\mathrm{F}$ pada taraf signifikansi 5 persen menunjukkan $\mathrm{F}=45,342 \geq 3,968=\mathrm{F}(\alpha=0,05: 1,75)$; 3) Latar belakang program studi dan jenis kelamin secara interaktif tidak berpengaruh terhadap tingkat sikap pemaafan mahasiswa. Hasil perhitungan nilai $\mathrm{F}$ pada taraf signifikansi 5 persen menunjukkan $\mathrm{F}=$ $12,530<3,119=\mathrm{F}(\alpha=0,05: 1,75)$. Pemaafan juga menjadi salah satu solusi atas berbagai permasalahan dan konflik antar manusia, sehingga dapat mengembalikan keharmonisan hubungan antara mereka.

Keywords: Sikap pemaafan, program studi, jenis kelamin, psikologi

\section{Pendahuluan}

Mahasiswa di perguruan tinggi, dari sisi perkembangan psikologis telah berada pada usia menuju kedewasaan (emerging adulthood). Masa dewasa awal merupakan masa ketegangan emosional karena sebagai manusia dalam kelompok usia hampir dewasa atau baru saja dewasa. Pada umumnya pada usia ini orang masih sekolah dan diambang memasuki dunia pekerjaan. Masa dewasa awal juga 
merupakan masa di mana mereka ingin merubah hal-hal yang tidak mereka sukai. ${ }^{1}$ Masa dewasa awal oleh Hurlock digambarkan dengan ciri-ciri antara lain: a) merupakan masa bermasalah, yakni masalah baru yang dari segi utamanya berbeda dengan dari masalah-masalah yang sudah dialami sebelumnya; b) sebagai masa ketegangan emosional; c) sebagai masa komitmen, sering merupakan masa ketergantungan, yaitu tergantung pada orang-orang tertentu dalam jangka waktu yang berbeda-beda, misalnya pada orang tua yang membiayai pendidikan; d) sebagai masa perubahan nilai. ${ }^{2}$

Keberadaan emosi yang semakin labil menjadi salah satu penanda ketika seseorang memasuki masa usia dewasa. Emosi digambarkan sebagai setiap kegiatan atau pergolakan pikiran, perasaan, nafsu, setiap keadaan mental yang hebat atau meluap-luap. Emosi merujuk pada suatu perasaan dan pikiran-pikiran khasnya, suatu keadaan biologis dan psikologis, dan serangkaian kecenderungan untuk bertindak. ${ }^{3}$ Emosi manusia, menurut Gohm and Clore, sebagaimana dikutip oleh Safaria \& Saputra, terbagi menjadi dua, yaitu emosi positif dan negatif. Emosi positif adalah emosi yang menenangkan dan menyenangkan seprti ceria, gembira, semangat, senang, rileks, dan lainlain. Emosi positif ini akan membuat keadaan psikologis manusia menjadi positif. Sebaliknya emosi negatif adalah emosi yang menyusahkan dan tidak menyenangkan, seperti marah, dendam, kecewa,

\footnotetext{
${ }^{1}$ Elizabeth B. Hurlock, Psikologi Perkembangan (Jakarta: Erlangga, 1990), hal. 249.

${ }^{2}$ Elizabeth B. Hurlock, Psikologi Perkembangan, hal. 250-251.

${ }^{3}$ Albert Sydney Hornby, Oxford Advanced Learner's Dictionary of Current English / [by] A.S. Hornby. Editor Jonathan Crowther. Oxford England: Oxford University Press, 1995.
} 
depresi, putus asa, frustasi. Emosi negatif ini akan membuat keadaan psikologis manusia menjadi negatif. Ketika manusia tidak mempu menyeimbangkan emosi negatif ini maka keadaan suasana hati menjadi buruk. $^{4}$

Kemampuan mengendalikan emosi oleh karenanya menjadi indikator kedewasaan mahasiswa. Kemampuan mengelola emosi merupakan kemampuan individu untuk menangani perasaan agar terungkap dengan tepat, dan selaras sehingga tercapai keseimbangan dalam diri individu. Kemampuan mengelola emosi mencakup kemampuan untuk menghibur diri, melepaskan kecemasan, kemurungan, atau ketersinggungan dari akibat-akibat yang ditimbulkannya serta kemampuan untuk bangkit dari perasaan-perasaan yang menekan. ${ }^{5}$ Orang yang mampu memahami emosi yang sedang mereka alami dan rasakan akan lebih mampu mengelola emosinya secara positif. Sebaliknya orang yang kesulitan memahami emosi yang mereka alami dan rasakan akan terpenjara oleh emosinya sendiri. Mereka akan menjadi bingung dan bimbang akan makna dari suasana emosi yang sedang mereka rasakan.

Usia mahasiswa merupakan tahapan bagi seseorang untuk mengenali potensi emosi yang ada dalam dirinya, dan kemudian belajar untuk mengendalikannya. Banyak cara dapat dilakukan untuk melakukan hal tersebut, antara lain melalui pendekatan agama. Agama, selain

\footnotetext{
${ }^{4}$ Safaria \& Saputra, Manajemen Emosi (Jakarta: Bumi Aksara, 2009), hal. 13

${ }^{5}$ Daniel Goleman, Emotional Intelligent, Kecerdasan Emosional; Mengapa EI Lebih Penting Daripada IQ (Jakarta: Gramedia Pustaka Utama, 1999) hal. 58.
} 
mengatur tentang tata cara berinteraksi dengan Tuhan, juga banyak mengajarkan nilai-nilai yang bermanfaat untuk menjalani hidup secara tertib, nyaman, tenteram dan damai. Agama juga mengajarkan bagaimana mengendalikan dari dari marah, sakit hati, dendam, sifat jahat, dan emosi. Nilai-nilai tersebut sesungguhnya adalah ajaran tentang bagaimana mengendalikan emosi.

Mahasiswa yang beragama dengan baik adalah orang yang memiliki potensi untuk mengendalikan emosinya dengan baik. Pengenalan yang baik terhadap agama pada mahasiswa akan memberinya petunjuk dan bimbingan dalam menyelesaikan permasalahan dalam hidupnya, termasuk permasalahan dalam berinteraksi dengan orang lain. Setidaknya mereka yang lebih baik pengenalan agamanya (religius) akan memiliki cara berhubungan yang lebih baik dengan orang lain, sehingga ketika terjadi permasalahan, maka mereka akan lebih mudah dalam menyelesaikannya. Sebaliknya pada mereka yang pengalaman religiusitasnya rendah akan cenderung membangun hubungan dengan orang lain secara tidak baik, sehingga ketika terjadi permasalahan pada hubungan tersebut akan kesulitan mencari solusinya. Salah satu etika yang mendasari hubungan yang baik menurut agama adalah kemampuan untuk memaafkan. ${ }^{6}$ Proses rekonsiliasi dan harmonisasi dalam rangka mengembalikan hubungan yang telah terganggu salah satunya dapat ditempuh dengan cara pemaafan.

${ }^{6}$ Moh. Khasan, "Perspektif Islam dan Psikologi tentang Pemaafan", Jurnal Al-Taqaddum, 9, 2017, hal. 69-94. 
Pemaafan adalah sejumlah perubahan motivasional seseorang yang menjadi: (a) berkurangnya motivasi untuk membalas melawan pihak yang menyerangnya; (b) berkurangnya motivasi untuk mempertahankan keterpisahan dari penyerang; dan (c) meningkatnya motivasi dengan konsiliasi dan kemauan baik (goodwill) kepada penyerang, meskipun tindakan penyerang menyakitkan. ${ }^{7}$ Dengan kata lain sesuai pendapat McCullough, dalam Dayakisni \& Hudaniah, bahwa pemaafan adalah penggantian dari emosi yang tidak memaafkan (misal benci, pahit, jengkel, bermusuh, marah, takut) dengan emosi yang berorientasi positif (cinta, empati, iba, atau simpati). Penggantian emosi ini memotivasi seseorang untuk menghentikan perilaku menghindari atau membalas dendam atau melawan terhadap orang yang telah menyakitinya, dan untuk mencari rekonsiliasi jika ini dirasa aman dan mungkin untuk dilakukannya juga. ${ }^{8}$

Pemaafan juga merupakan sebuah reframe karena ia memungkinkan seseorang untuk melihat dan mengalami (memperlakukan) kejadian masa lalu yang menyakitkan dengan cara pandang yang berbeda. Pemaafan juga merupakan agen pemberdayaan sementara karena ia merubah keseimbangan kekuasaan dalam sebuah hubungan. Biasanya, kekuasaan terletak pada pelanggar (pelaku). Selain itu, pengampunan bertindak secara paradoks untuk melepaskan (meredakan) konflik dua belah pihak karena ia menghilangkan banyak

\footnotetext{
${ }^{7}$ M.E, Worthington McCullough, E.L, and Rachal, K.C., "Interpersonal Forgiving in Close Relationships," Journal of Personality and Social Psychology 73 (2), 1997.

${ }^{8}$ Lihat: Tri Dayakisni \& Hudaniah, Psikologi Sosial, (Malang: UMM Press, 2009)
} 
kebingungan yang muncul dengan perasaan ambivalensi seputar pelanggaran itu.

Namun demikian menjadi pemaaf ternyata tidak mudah. Bahkan terhadap kesalahan yang kecil dan mungkin tidak disengaja sekalipun, terkadang seorang sulit untuk melupakan perbuatan orang lain yang melakukannya. Yang terjadi justru penyimpanan perasaan sakit hati, benci, marah, dan balas dendam dalam hati dan cenderung menjaga jarak dengan si pelaku. Oleh karena itu membentuk perilaku pemaaf tidak bisa secara kebetulan, melainkan dengan pendidikan dan latihan secara serius. Orang berpendidikan dianggap lebih berpotensi untuk menjadi pemaaf, disebabkan oleh kemampuan dirinya yang telah terlatih dalam dunia pendidikan untuk mengelola dan mengendalikan emosinya. Dengan demikian, semakin tinggi tingkat pendidikan seseorang, semakin tinggi pula potensi untuk dapat memaafkan orang lain dan menjadi pemaaf.

Pemaafan dapat terjadi karena adanya dua dimensi yang terbentuk yaitu intrapsikis dan interpersonal. Dimensi intrapsikis melibatkan keadaan dan proses yang terjadi di dalam diri orang yang disakiti secara emosional maupun pikiran dan perilaku yang menyertainya. Sedangkan dimensi interpersonal lebih melihat bahwa memaafkan orang lain merupakan tindakan sosial antara sesama manusia. Maksudnya adalah langkah menuju mengembalikan hubungan

9 Sue Walrond Skinner, "The Function and Role of Forgiveness in Working with Couples and Families: Clearing the Ground", Journal of Family Therapy, Vol. 20 (USA: The Association for Family Therapy 1998), hal. 9-19. 
kepada kondisi semula sebelum peristiwa yang menyakitkan terjadi. Dimensi intrapsikis dan dimensi interpersonal ini saling berinteraksi dan akan menghasilkan beberapa kombinasi pemaafan, seperti bollow forgiveness, silent forgiveness, total forgiveness, dan no forgiveness. ${ }^{10}$ Sebagai fenomena intrapsikis, pemaafan dipengaruhi oleh beberapa faktor, baik internal maupun eksternal. Faktor internal diantaranya adalah keberagamaan (religiusitas) ${ }^{11}$, empati, jenis kelamin ${ }^{12}$, penyesalan, dan kematangan diri (self maturity). ${ }^{13}$ Sedangkan faktor eksternal, diantaranya adalah faktor tingkat pendidikan.

${ }^{10}$ R. F. Baumeister, J. J. Exline, and K. L. Sommer, "The Victim Role, Grudge Theory, and Two Dimensions of Forgiveness" dalam Everett L. Worthington Jr, Dimension of Forgiveness, Psychological Research and Theological Perspective, Templeton, 1998.

${ }^{11}$ Baca: Eluzia Yulitasari, "Hubungan religiusitas dan pemaafan pada pelayan gereja Isa al-Masih Pati," Skripsi, 2016; Anisa Prihantini, "Hubungan Religiusitas dan Kecerdasan Emosi dengan Perilaku Pemaafan pada Wanita Janda," Skripsi, 2016; Furqon Firmansyah, "Hubungan Religiusitas dan Pemaafan pada Mahasiswa Psikologi UIN Sunan Ampel yang Tinggal di Ma'had Sunan Ampel al-'Aly," Thesis, 2012; Aliah B. Purwakania Hasan, "Pemaafan sebagai Variabel Moderator pada Pengaruh Religiusitas dengan Agresi Relasional di Kalangan Mahasiswa Universitas Berbasis Nilai-nilai Islam” Jurnal Al-Ažbar Indonesia Seri Humaniora, Vol . 2, No. 1, Maret 2013; Ni Made Taganing Kurniati, "Studi Meta-Analisis Hubungan Religiusitas dan Pemaafan", Jurnal Ilmu Psikologi, vol. 5 no. 1, 2011.

12 Hestiyani Agustina, "Perbedaan Pemaafan Ditinjau dari Jenis Kelamin", Skripsi, Universitas Muhammadiyah Malang, 2009, hal. 49 - 52; Tahmidiyah Ghuzairoh, "Perbedaaan Forgiveness Ditinjau dari Jenis Kelamin Pada Budaya Jawa," Skripsi, UIN Maulana Malik Ibrahim Malang, 2015; Sayed Ichsan, "Perbedaan Pemaafan (Forgiveness) Pada Pasangan yang Bercerai di Kota Banda Aceh Ditinjau dari Jenis Kelamin" Thesis, Universitas Syiah Kuala Banda Aceh, 2016; Fuad Nashori, "Pemaafan pada Etnis Jawa Ditinjau dari Faktor Demografi," Jurnal Psikologika Vol 18 No. 2 Tahun 2013, hal. 119.

${ }^{13}$ Ilsan Sumiati dan Stefanus Soejanto Sandjaja menyatakan bahwa tidak ada hubungan antara jenis kelamin dengan pemaafan, namun pemaafan memiliki hubungan yang kuat dengan kematangan diri (self maturity) seseorang. Baca: Ilsan Sumiati, \& Stefanus Soejanto Sandjaja, "Hubungan antara Pemaafan dan Kematangan Diri pada Remaja Akhir", Jurnal Noetic Psychology vol. 3 no. 2, 2013. 
Jenis kelamin juga dianggap sebagai faktor intrapsikis yang mempengaruhi sikap pemaafan. Agustina dalam penelitiannya menyatakan bahwa terdapat perbedaan sikap pemaafan yang sangat signifikan antara laki-laki dan perempuan. Dalam kesimpulannya, lakilaki memiliki tingkat pemaafan yang cenderung lebih tinggi dibandingkan dengan perempuan. ${ }^{14}$ Berbeda dengan Agustina, Nashori dan Ilsan Sumiati \& Stefanus Soejanto Sandjaja menemukan bahwa tidak ada pengaruh langsung antara jenis kelamin dengan pemaafan. Jenis kelamin laki-laki maupun perempuan tidak memberikan kontribusi secara signifikan terhadap ada atau tidaknya karakter pemaaf pada diri seseorang. ${ }^{15}$

Adapun sebagai fenomena interpersonal, pemaafan salah satunya dipengaruhi oleh faktor pendidikan. Hal ini setidaknya sebagaimana temuan penelitian Nashori tentang pemaafan, yang menyatakan bahwa semakin tinggi tingkat pendidikan, seseorang cenderung memiliki sikap pemaafan yang lebih tinggi. Nashori juga mengatakan bahwa potensi pemaafan pada Pendidikan Tinggi lebih tinggi dari pemaafan pada pendidikan SMP/MTs dan SMA/SMK/MA. ${ }^{16}$

Lembaga pendidikan tinggi adalah sebuah lembaga yang menjadi tempat terjadinya transformasi ilmu pengetahuan secara sistematis yang

14 Hestiyani Agustina, "Perbedaan Pemaafan Ditinjau dari Jenis Kelamin", Skripsi, (Universitas Muhammadiyah Malang, 2009), hal. 49 - 52.

15 Lihat: Fuad Nashori, "Pemaafan pada Etnis Jawa Ditinjau dari Faktor Demografi", hal. 119; Ilsan Sumiati \& Stefanus Soejanto Sandjaja, "Hubungan antara Pemaafan dan Kematangan Diri pada Remaja Akhir"

${ }^{16}$ Fuad Nashori, "Pemaafan pada Etnis Jawa Ditinjau dari Faktor Demografi”, hal. 119. 
diharapkan dapat merubah cara berpikir dan perilaku orang-orang dewasa yang terlibat di dalamnya. Menggunakan asumsi adanya pengaruh antara tingkat pendidikan dengan sikap pemaafan di atas, maka menjadi menarik untuk menindaklanjuti penelitian tersebut dengan penelitian yang lain, terlebih dengan variabel yang lebih kuat. Penelitian ini bermaksud menguji adanya pengaruh tingkat pendidikan terhadap sikap pemaafan dikombinasikan dengan variabel jenis kelamin pada lembaga pendidikan tinggi Islam. Penelitian ini memiliki variasi fokus yang berbeda, yaitu melihat perbedaan sikap pemaafan tersebut berdasarkan pada perbedaan program studi serta perbedaan jenis kelamin dan interaksi antara keduanya.

\section{Kerangka Teori}

\section{Sikap Pemaafan}

Sikap merupakan ekspresi terpenting dari perilaku manusia. Sikap juga merupakan simbolisasi dari keyakinan dan prinsip seseorang. Istilah sikap banyak digunakan untuk menunjukkan keadaan jiwa sesorang yang mendorong untuk melakukan suatu tindakan. Oxford mendefinisikan sikap (Inggris: attitude) sebagai: a way of thingking about somebady or something or behaving toward somebady or something. ${ }^{17}$ Sementara itu menurut Kamus Umum Bahasa Indonesia (KUBI), sikap adalah perbuatan dan sebagainya yang berdasar pendirian

\footnotetext{
17 Albert Sydney Hornby, Oxford Advanced Learner's Dictionary of Current English / [by] A.S.
} Hornby ; Editor Jonathan Crowther (Oxford, England :Oxford University Press, 1995), hal. 66. 
(pendapat/keyakinan). ${ }^{18}$ Jadi sikap memiliki karakteristik yang mengarah pada perilaku, baik positif maupun negatif, terhadap objeknya. Hal ini setidaknya menurut Vaughan \& Hogg, sebagaimana dikutip Baroroh bahwa sikap merupakan organisasi keyakinan, perasaan dan kecenderungan bertindak terhadap objek sosial, kelompok, peristiwa, atau simbol yang relatif abadi. Sikap bukan merupakan suatu yang spontanitas dalam menghadapi suatu objek, tetapi merupakan suatu yang sudah terpola dan terbentuk melalui proses yang panjang. ${ }^{19}$

Adapun kata al-'afw terulang dalam Al-Qur'an sebanyak 34 kali. Menurut Quraish Shihab, kata ini pada mulanya berarti berlebihan (QS [2]: 219). Maksudnya, yang berlebih seharusnya diberikan agar keluar. Keduanya menjadikan sesuatu yang tadinya berada di dalam (dimiliki) menjadi tidak di dalam dan tidak dimiliki lagi. Akhirnya kata al-'afw berkembang maknanya menjadi keterhapusan. Memaafkan, berarti menghapus luka atau bekas-bekas luka yang ada di dalam hati. ${ }^{20}$ Beberapa ayat al-Qur'an, kata "al-'afw" dipasangkan dengan nama Allah yang lain yaitu "al-Ghafûr" (maha pengampun), seperti dalam surat anNisa': 43 dan an-Nisa': 99. Kedua nama Allah yang maha indah ini memang memiliki makna yang hampir sama. Nama Allah al-Afun memiliki makna yang lebih mendalam karena "pengampunan" mengisyaratkan arti al-sitr (menutupi), sedangkan "pemaafan"

18 W.J.S. Poerwadarminta, Kamus Umum Bahasa Indonesia (Jakarta: Balai Pustaka, 2010), hal. 1120.

19 Lihat: Umul Baroroh, "Pengaruh Tingkat Kebergamaan dan Fundamentalisme Keagamaan terhadap Persepsi tentang Kesetaraan Gender, Sikap terhadap Nikah Sirri, dan Respons pada Rencana Legislasi Nikah Sirri," Disertasi, UIN Walisongo Semarang, 2012, hal. 29.

${ }^{20}$ M. Quraish Shihab, Tafsir Tematike atas Pelbagai Persoalan Umat (Bandung: Mizan, 2007), hal. 326-327. 
mengisyaratkan arti al-mahn $w$ (menghapuskan) yang artinya lebih mendalam (dalam penghapusan dosa). Meskipun demikian, kedua nama Allah ini jika disebutkan sendiri-sendiri maknanya mencakup keseluruhan arti tersebut. $^{21}$

Pemaafan adalah "aktivitas memaafkan atau kondisi menjadi termaafkan atau kemauan untuk memaafkan sesuatu atau seseorang" Definisi ini dianggap tidak secara jelas memberikan pemahaman tentang konsep tersebut, namun menunjukkan bahwa pemaafan dapat berupa sesuatu kondisi yang aktif (pemberian maaf) maupun pasif (menerima maaf). ${ }^{22}$ Secara aktif, pemaafan juga diartikan sebagai "berhenti untuk merasakan dendam terhadap sebuah kesalahan tertentu yang dilakukan, untuk menyerahkan klaim pembalasan atau ganti rugi kepada pelaku, untuk membebaskan, untuk memaafkan", 23

Pemaafan (forgiveness) dalam diskursus ilmu psikologi didefinisikan dalam berbagai perspektif. Pemaafan bertindak sebagai sebuah reframe karena ia memungkinkan seseorang untuk melihat dan mengalami (memperlakukan) kejadian masa lalu yang menyakitkan dengan cara pandang yang berbeda. Pemaafan juga merupakan agen pemberdayaan sementara karena ia merubah keseimbangan kekuasaan dalam sebuah hubungan. Biasanya, kekuasaan terletak pada pelanggar (pelaku). Selain itu, pemaafan bertindak secara paradoks untuk melepaskan (meredakan) konflik dua belah pihak karena ia menghilangkan banyak kebingungan

${ }^{21}$ Abdurrazzaq bin Abdul Muhsin al-Abbad al-Badr, Fikih Asmaul Husna, cet.5 (Jakarta: Darus Sunnah Press, 2011), hal. 142.

22 Albert Sydney Hornby, Oxford Advanced Learner's Dictionary of Current English / [by] A.S. Hornby ; Editor Jonathan Crowther (Oxford, England: Oxford University Press, 1995), hal. 463.

23 Webster's New College Dictionary, Webster's New World College Dictionary, Third Edition (New York: A Simon and Schuster McMillan Company, 1996), hal. 529. 
yang muncul dengan perasaan ambivalensi seputar pelanggaran itu. ${ }^{24}$ Pemafaan juga dipahami sebagai perubahan motivasional, menurunnya motivasi untuk balas dendam dan motivasi untuk menghindar dari orang yang telah menyakiti, yang cenderung mencegah seseorang merespons yang destruktif dalam interaksi sosial dan mendorong seseorang untuk menunjukkan perilaku yang konstruktif terhadap orang yang telah menyakitinya. ${ }^{25}$

Berdasarkan beberapa definisi di atas disimpulkan bahwa pengertian pemaafan adalah upaya untuk mengatasi permasalahan psikologis dan sosial seperti sakit hati, marah, dan keinginan balas dendam akibat perbuatan orang lain yang berpotensi merusak hubungan dengan pelaku dengan cara merekonstruksi dan membangun hubungan yang lebih baik.

\section{Aspek dan Dimensi Pemaafan}

Pemaafan diukur dengan menggunakan skala yang disebut sebagai skala pemaafan (forgiveness scale). Skala pemaafan ini terdiri dari tiga subskala: perasaan (feeling), pemikiran (thought), dan behaviors

\footnotetext{
${ }^{24}$ Sue Walrond Skinner, "The Function and Role of Forgiveness in Working with Couples and Families: Clearing the Ground", hal. 9-19; L.Y. Thompson, Snyder, C.R., Hoffman, L., Michael, S.T., Rasmussen, H.N., Billings, L.S., Heinze, L., Neufeld, J.E., Shorey, H.S., Roberts, J.C., \& Robert, D.E., Dispositional Fogiveness of Self, Other, and Situation, Journal of Social and Personality Psychology, 73 (2)., 2005, hal. 313-359.

25 M.E McCullough, Wortington, E.L, and Rachal, K.C., "Interpersonal Forgiving in Close Relationships", Journal of Personality and Social Psychology 73 (2), 1997, hal. 321.; T.W. Baskin \& R.D. Enright, "Intervention Studies on Forgiveness: A Meta-Analysis", Journal of Counseling \& Development, Vol. 82 (Winter), 2004, hal. 20; M.E. McCullough, Fincham, F.D and Tsang, J., "Forgiveness, Forbearance and Time : The Temporal Unfolding of Transgression-Related Interpersonal Motivations." Journal of Personality and Social Psychology, 84 (3), 2003, hal. 540; Michael E. McCullough, "Forgiveness as Human Strength: Theory, Measurement, and Links to Well-Being," Journal of Social and Clinical Psychology, Spring 2000; 19, 1., hal. 43-55.
} 
(perilaku). Subskala ini memungkinkan peneliti untuk mengukur tiga komponen tertentu dari pemaafan. Subskala feeling, diukur dengan bentuk negative feelings: kebencian (hatred), amukan (rage), and kemarahan (anger) dan positive feelings: peduli (care), belas kasihan (compassionate), dan penerimaan (acceptance). Secara kognitif (thought), pemaafan diukur dengan pertanyaan-pertanyaan yang memfokuskan pada kebebasan dari: godaan (obsession), penguatan (affirmation), balas dendam (revenge), dan: penipuan/viktimisasi (victimization). Adapun pada subskala perilaku (behaviors), pemaafan diukur dalam bentuk penerimaan terhadap takdir Tuhan (toward God), perdamaian (conciliation), dan menaruh dendam (bolding a grudge). ${ }^{26}$

Adapun mengenai dimensi pemaafan, Nashori mengklasifikasikannya menjadi tiga, yaitu: emosi, kognisi, dan interpersonal. Indikator dimensi emosi meliputi: a) meninggalkan perasaan marah, sakit hati, benci; b) mampu mengontrol emosi saat diperlakukan tak menyenangkan; c) perasaan iba dan kasih sayang terhadap pelaku; d) perasaan nyaman ketika berinteraksi dengan pelaku. Indikator dimensi kognisi meliputi: a) meninggalkan penilaian negatif terhadap pelaku; b) punya penjelasan nalar atas perlakuan yang menyakitkan; c) Memiliki pandangan yang berimbang terhadap pelaku. Sedangkan indikator dimensi interpersonal meliputi: a) meninggalkan perilaku atau perkataan yang menyakitkan terhadap pelaku; b) meninggalkan keinginan balas dendam; c) meninggalkan perilaku acuh tak acuh; d) meninggalkan perilaku menghindar; e) meningkatkan upaya

${ }^{26}$ S.B., Gorsuch Wade, R., \& Rosik, C.H., "The development of a scale to measure forgiveness," Journal of Psychology and Christianity, 1990, hal. 40-52. 
konsiliasi/rekonsiliasi hubungan; f) motivasi kebaikan atau kemurahan hati; dan g) musyawarah dengan pihak yang pernah jadi pelaku. ${ }^{27}$

\section{Pemaafan, Hubungannya dengan Pendidikan dan Jenis Kelamin serta Faktor-Faktor Lain yang Mempengaruhinya}

Sebagai fenomena intrapsikis, pemaafan dipengaruhi oleh beberapa faktor, baik internal maupun eksternal. Faktor internal diantaranya adalah keberagamaan, empati, dan penyesalan. Sedangkan faktor eksternal, diantaranya adalah faktor tingkat pendidikan. Poloma dan Gallup sebagaimana dikutip Bedell menemukan bahwa 65\% orang Amerika melaporkan pentingnya bagi seseorang yang beragama untuk memaafkan yang lain yang memiliki salah terhadap mereka. Ada hubungan yang kuat antara pengampunan yang serius (sungguhsungguh) dengan komitmen keagamaan, keanggotaan gereja, dan kehadiran ke gereja. ${ }^{28}$ Demikian juga, dalam General Social Survey (1998), bahwa seseorang yang menghadiri pelayanan gereja lebih dari sekali seminggu, memaafkan 20\% lebih banyak daripada mereka yang hadir secara mingguan dan rata-rata 50\% lebih banyak dari mereka yang tidak pernah menghadiri pelayanan gereja. Penyesalan dan empati menjadi faktor yang secara positif juga berpengaruh terhada pemaafan. Pada dasarnya, sulit bagi seseorang untuk memaafkan orang lain ketika orang

${ }^{27}$ Fuad Nashori, "Meningkatkan Kualitas Hidup dengan Pemaafan", Unisia, Vol. 33 No. 75 Juli 2011, hal. 217-219.

28 Tina Marie Bedell, "The Role of Religiosity in Forgiveness", Dissertation (Ohio: Ohio State University, 2002), hal. 6. 
tersebut tidak mengakui bahwa ia telah melakukan kesalahan atau bertanggung jawab atas perbuatan salah mereka. ${ }^{29}$

Jenis kelamin juga dianggap sebagai faktor yang mempengaruhi sikap pemaafan. Agustina dalam penelitiannya menyatakan bahwa terdapat perbedaan sikap pemaafan yang sangat signifikan antara lakilaki dan perempuan. Hal ini ditunjukkan dengan hasil analisa $t$ test sebesar 2,760 dengan nilai signifikan sebesar 0,007 <0,01. Diketahui dari hasil penelitian tersebut bahwa laki-laki memiliki tingkat pemaafan sebesar 77,92 dan perempuan sebesar 73,15. Hal ini dapat diartikan bahwa laki-laki memiliki tingkat pemaafan yang cenderung lebih tinggi dibandingkan dengan perempuan. $^{30}$ Berbeda dengan itu, Nashori menyimpulkan bahwa tidak ada pengaruh langsung antara jenis kelamin dengan pemaafan. Jenis kelamin laki-laki maupun perempuan tidak memberikan kontribusi secara signifikan terhadap ada atau tidaknya karakter pemaaf pada diri seseorang. ${ }^{31}$ Dalam kaitan dengan hal ini penelitian ini menjadi penting mengingat adanya potensi perbedaan sikap pemaafan antara laki-laki dan perempuan.

Laki-laki dan perempuan memiliki perbedaan prinsip yang universal dalam masyarakat. Keduanya memiliki perbedaan dari beberapa segi baik fisik, karakteristik dan emosi. Perempuan umumnya lebih bersifat tidak agresif, memelihara, emosional lemah lembut, dan keibuan sehingga cenderung sensitif. Sedangkan laki-laki cenderung bersifat agresif dan penuh daya serang untuk menguasai situasi ruang

\footnotetext{
${ }^{29}$ M.E McCullough, E.L. Worthington, K.C. Rachal, "Interpersonal Forgiving in Close Relationships", hal. 321.

${ }^{30}$ Hestiyani Agustina, "Perbedaan Pemaafan Ditinjau dari Jenis Kelamin", hal. 49 - 52.

${ }^{31}$ Fuad Nashori, "Pemaafan pada Etnis Jawa", hal. 119.
} 
lingkup hidupnya, namun diyakini juga sebagai lebih rasional. Berdasarkan perbedaan tersebut maka kemungkinan perempuan akan lebih sulit untuk memaafkan daripada laki-laki ketika disakiti orang lain karena lebih dominannya emosi dan perasaan dalam setiap pengambilan keputusannya.

Sebagai fenomena interpersonal, pemaafan antara lain dipengaruhi oleh faktor pendidikan. Hal ini setidaknya sebagimana temuan penelitian Nashori bahwa semakin tinggi tingkat pendidikan seseorang cenderung memiliki sikap pemaafan yang lebih tinggi. Nashori juga mengatakan bahwa pemaafan pada Pendidikan Tinggi lebih tinggi dari pemaafan pada pendidikan SMP/MTs dan SMA/SMK/MA. ${ }^{32}$

\section{Metode Penelitian}

\section{Subjek Penelitian}

Penelitian ini merupakan penelitian kuantitatif. Subjek dalam penelitian ini adalah mahasiswa Universitas Islam Negeri (UIN) Walisongo Semarang. Populasi dalam penelitian ini adalah mahasiswa aktif Fakultas Syari'ah dan Hukum UIN Walisongo Semarang angkatan 2013. Adapun pengambilan sampel dalam penelitian ini dilakukan dengan cluster random sampling, yaitu cara pengambilan sampel secara random terhadap kelompok-kelompok yang ada dalam populasi. Jumlah sampel dalam penelitian ini adalah 81 mahasiswa. Besarnya jumlah sampel dalam penelitian ini didasarkan pendapat Azwar yang

\footnotetext{
32 Fuad Nashori, "Pemaafan pada Etnis Jawa", hal. 119.
} 
menyebutkan bahwa jumlah minimal sampel adalah tiga kali jumlah aitem penelitian. ${ }^{33}$ Pada penelitian ini, jumlah aitem keseluruhan adalah 27 aitem, sehingga penelitian ini membutuhkan 81 subjek (3 x 27 aitem). Subjek penelitian tersebut tersebar pada tiga prodi, yaitu prodi AS 24 orang, prodi MU 15 orang, dan prodi JS 42 orang.

\section{Metode Pengumpulan Data}

Instrumen yang digunakan untuk mengumpulkan data merupakan instrumen hasil pengembangan dan modifikasi dari skala pemaafan yang disusun oleh Nashori (2012) dalam penelitian sebelumnya. Sikap pemaafan diukur berdasarkan beberapa dimensi dan indikator, mencakup yang favorable maupun unfavorable. Dimensi sikap pemaafan diklasifikasikan menjadi tiga, yaitu dimensi emosi, dimensi kognisi, dan dimensi interpersonal. Masing-masing dimensi kemudian diuraikan menjadi faktor-faktor. Dimensi emosi meliputi faktor-faktor: meninggalkan perasaan marah, sakit hati, benci; mampu mengontrol emosi saat diperlakukan tidak menyenangkan; perasaan iba dan kasih sayang terhadap pelaku, dan perasaan nyaman ketika berinteraksi dengan pelaku. Dimensi kognisi meliputi faktor-faktor: meninggalkan penilaian negatif terhadap pelaku; punya penjelasan nalar atas perlakuan yang menyakitkan; dan memiliki pandangan yang berimbang terhadap pelaku. Sedangkan dimensi interpersonal meliputi faktor-faktor: meninggalkan perilaku atau perkataan yang menyakitkan terhadap pelaku; meninggalkan keinginan balas dendam; meninggalkan perilaku acuh tak acuh; meninggalkan perilaku menghindar; motivasi kebaikan

\footnotetext{
${ }^{33}$ Lihat: Saifuddin Azwar, Metode Penelitian (Yogyakarta: Pustaka Pelajar, 2013).
} 
atau kemurahan hati; meningkatkan upaya konsiliasi/rekonsiliasi hubungan; dan musyawarah dengan pihak yang pernah jadi pelaku. ${ }^{34}$ Tinggi rendahnya sikap pemaafan diukur dengan skor pemaafan. Semakin tinggi skor sikap pemaafan semakin tinggi pemaafan responden.

Skala pengukuran ini terdiri dari tiga dimensi dan 14 indikator, yaitu: dimensi emosi (4 indikator), dimensi kognisi (3 indikator), dan dimensi interpersonal (7 indikator). Instrumen sikap pemaafan ini terdiri dari 27 butir. Model skala yang digunakan adalah model skala ordinal dengan lima alternatif jawaban, yaitu sangat setuju (SS), setuju (S), raguragu (R), tidak setuju (TS), dan sangat tidak setuju (STS). Setiap butir disusun dalam bentuk pernyataan positif (favorable) yang merupakan pernyataan yang sesuai atau mendukung sikap pemaafan, atau pernyataan negatif (unfavorable), yang merupakan pernyataan yang tidak sesuai atau tidak mendukung sikap pemaafan.

Terhadap jawaban responden, kemudian dilakukan penskoran. Masing-masing butir memiliki skor bervariasi antara 1 (menunjukkan sikap pemaafan rendah) hingga 5 (menunjukkan sikap pemaafan tinggi). Untuk butir dengan bentuk pernyataan positif, skor merentang dari 5 hingga 1 secara berturut-turut untuk SS, S, R, TS, dan STS. Sedangkan butir dengan bentuk pernyataan negatif, skor merentang 1 hingga 5 , secara berturut-turut untuk STS, TS, R, S, dan SS.

\section{Metode Analisis Data}

34 Fuad Nashori, "Meningkatkan Kualitas Hidup dengan Pemaafan", Unisia, hal. 217219. 
Sesuai dengan permasalahan penelitian, teknik analisis data yang digunakan adalah analisis varian dua jalur atau two-path analysis of variance yang juga disebut dengan rancangan dua-jalur atau two-way layout. Teknik ini dimaksudkan untuk mengungkap pengaruh utama maupun interaktif dari kedua variabel independen (latar belakang prodi dan jenis kelamin terhadap variabel dependen (sikap pemaafan) secara simultan.

\section{Hasil Penelitian}

\section{Analisis Deskriptif}

Sebagaimana disampaikan dalam bab sebelumnya bahwa penelitian ini bertujuan untuk mengetahui perbedaan tingkat pemaafan mahasiswa berdasarkan latar belakang prodi, jenis kelamin, serta interaksi antara keduanya. Adapun hipotesis yang diajukan ada tiga, yaitu: pertama, mahasiswa dalam prodi JS memiliki tingkat sikap pemaafan lebih tinggi dibanding mahasiswa prodi AS dan MU; kedua, mahasiswa laki-laki memiliki tingkat sikap pemaafan lebih tinggi dibanding mahasiswa dengan mahasiswa perempuan; dan ketiga, latar belakang prodi dan jenis kelamin secara interaktif mempunyai pengaruh terhadap sikap pemaafan.

Untuk menguji kebenaran hipotesis dan kajian teori di atas, maka perlu dicermati hasil analisis Varian Dua Jalur dalam penelitian ini sebagaimana ditampilkan dalam tabel berikut:

Tebel 1 Hasil Analisis Data

\begin{tabular}{|c|c|c|c|c|}
\hline Jenis & & Pro & & Totol \\
\hline Kelamin (B) & AS (A1) & MU (A2) & JS (A3) & 10 \\
\hline
\end{tabular}




\begin{tabular}{lllll}
\hline & & $\mathrm{N} 21=4$ & $\mathrm{~N} 31=35$ & \\
Laki-laki (B1) & $\mathrm{N} 11=10$ & $\mathrm{M} 21=$ & $\mathrm{M} 31=$ & $\mathrm{N} \cdot 1=49$ \\
& $\mathrm{M} 11=85,300$ & 87,500 & 92,229 & $\mathrm{M} \cdot 1=90,429$ \\
& $\mathrm{~S} 11=2,541$ & $\mathrm{~S} 21=$ & $\mathrm{S} 31=$ & $\mathrm{S} \cdot 1=4,077$ \\
& & 1,732 & 3,069 & \\
\hline \multirow{4}{*}{ Perempuan } & $\mathrm{N} 12=14$ & $\mathrm{~N} 22=11$ & $\mathrm{~N} 22=7$ & \\
(B2) & $\mathrm{M} 12=81,929$ & 82,909 & $\mathrm{M} 32=$ & $\mathrm{N} \cdot 2=32$ \\
& $\mathrm{~S} 12=4,843$ & $\mathrm{~S} 22=$ & 87,429 & $\mathrm{M} \cdot 2=83,469$ \\
& & 3,506 & $\mathrm{~S} 32=$ & $\mathrm{S} \cdot 2=4,853$ \\
& & $\mathrm{~N} 2 \cdot=15$ & $\mathrm{~N} 3 \cdot 094$ & \\
Total & $\mathrm{N} 1 \cdot=24$ & $\mathrm{M} 2 \cdot=$ & $\mathrm{M} 3 \cdot=$ & $\mathrm{N} \cdot \bullet=81$ \\
& $\mathrm{M} 1 \bullet=83,333$ & 84,133 & 91,429 & $\mathrm{M} \cdot \bullet=87,704$ \\
& $\mathrm{~S} 1 \bullet=4,320$ & $\mathrm{~S} 2 \cdot=$ & $\mathrm{S} 3 \cdot=$ & $\mathrm{S} \cdot \bullet=5,142$ \\
& & 3,720 & 3,858 & \\
\hline
\end{tabular}

Hasil analisis deskriptif sebagaimana ditampilkan dalam tabel menunjukkan adanya perbedaan nilai rata-rata dan simpang baku skor pemaafan dari ketiga prodi. Rata-rata skor pemaafan mahasiswa prodi JS lebih tinggi dari pada rata-rata mahasiswa prodi AS dan MU. Nilai ratarata sikap pemaafan untuk ketiga prodi secara berturut-turut adalah $\mathrm{M} 3 \cdot=91,429 ; \quad \mathrm{M} 2 \bullet=84,133 ;$ dan $\mathrm{M} 1 \bullet=83,333$. Sementara itu penyebaran skor mahasiswa dalam prodi selain JS cenderung bervariasi, ada yang lebih banyak dan lebih sedikit (prodi AS: s1 $\bullet=4,320$; prodi Muamalah: S2 $\bullet=3,720)$. Penyebaran skor mahasiswa prodi JS sendiri adalah S3・ $=3,858$.

Tabel diatas juga menunjukkan bahwa ada perbedaan rata-rata sikap pemaafan antara kelompok laki-laki dan kelompok perempuan. Rata-rata sikap pemaafan pada mahasiswa laki-laki lebih tinggi dari pada rata-rata sikap pemaafan mahasiswa perempuan. Mahasiswa laki-laki memiliki nilai rata-rata sebesar $\mathbf{M} \bullet 1=90,429$, sedangkan niali rata-rata mahasiswa perempuan sebesar $\mathrm{M} \cdot 2=83,469$. 
Selanjutnya dari tabel tersebut dapat ditemukan bahwa terdapat variasi pada nilai rata-rata yang diperoleh mahasiswa antar sel/kelompok interaksi. Mahasiswa yang berada dalam kelompok (prodi) JS cenderung memiliki tingkat pemaafan lebih tinggi dibanding mahasiswa dalam selsel/kelompok prodi AS dan MU. Nilai rata-rata mahasiswa prodi JS berturut-turut antara M31 $=92,229$ untuk laki-laki dan M32 $=87,429$ untuk perempuan. Nilai rata-rata ini lebih tinggi dibanding nilai rata-rata prodi AS, yaitu: $\mathrm{M} 11=85,300$ dan $\mathrm{M} 12=81,929$, dan nilai rata-rata prodi MU, yaitu: M21 $=87,500$ dan $\mathrm{M} 22=82,909$, untuk laki-laki dan perempuan.

Adapun berkenaan dengan penyebaran skor mahasiswa menunjukkan kecenderungan berbeda antar kelompok interaksi. Di lingkungan prodi JS, mahasiswa laki-laki cenderung lebih homogin dibanding mahasiswa perempuan (skor baku masing-masing adalah S31 $=3,069$ dan $\mathrm{S} 32=5,094$. Namun kecenderungan ini juga terjadi pada mahasiswa prodi yang lain, yaitu AS (s11 = 2,541 dan s12 = 4,843) dan Muamalah (S21 = 1,732 dan S22 = 3,506). Dengan demikian baik prodi JS, AS, maupun MU, memiliki kecenderungan yang sama bahwa penyebaran skor laki-laki lebih homogin daripada perempuan.

\section{Uji Hipotesis}

Hasil analisis deskriptif menunjukkan adanya perbedaan kecenderungan tingkat pemaafan pada mahasiswa yang berada pada kelompok dan sel yang berbeda. Untuk membuktikan apakah kesimpulan tersebut memiliki tingkat signifikansi yang kuat ataukah 
tidak, maka digunakan analisis varian dua jalur. Hasil analisis tersebut sebagai berikut:

Tabel 2 Uji Hipotesis

\begin{tabular}{|c|c|c|c|c|c|c|}
\hline $\begin{array}{l}\text { Sumber } \\
\text { Varian }\end{array}$ & JK & $\mathbf{k}$ & RJK & $\mathbf{F}$ & $(\alpha=0,05)$ & $\begin{array}{l}\text { Kesimpul } \\
\text { an }\end{array}$ \\
\hline $\begin{array}{l}\text { Program } \\
\text { Studi (A) }\end{array}$ & 881,537 & & 440,768 & $\begin{array}{l}34,05 \\
1\end{array}$ & 3,119 & Signifikan \\
\hline $\begin{array}{l}\text { Jenis } \\
\text { Kelamin } \\
\text { (B) }\end{array}$ & 586,920 & & 586,920 & $\begin{array}{l}45,34 \\
2\end{array}$ & 3,968 & Signifikan \\
\hline $\begin{array}{l}\text { Interaksi A } \\
\& \mathrm{~B}\end{array}$ & $\begin{array}{l}- \\
324,391\end{array}$ & & 162,196 & 2,530 & 3,119 & $\begin{array}{c}\text { Tidak } \\
\text { Signifikan }\end{array}$ \\
\hline $\begin{array}{l}\text { Dalam } \\
\text { Kelompok }\end{array}$ & $\begin{array}{l}970 \\
823\end{array}$ & 5 & 12,944 & & & \\
\hline TOTAL & $\begin{array}{l}2114,88 \\
9\end{array}$ & 0 & & & & \\
\hline
\end{tabular}

Hasil analisis sebagaimana disajikan dalam tabel tersebut memperlihatkan bahwa kedua faktor (latar belakang prodi dan jenis kelamin) memiliki pengaruh signifikan pada tingkat sikap pemaafan mahasiswa secara terpisah. Akan tetapi secara interaktif, kedua faktor tidak memiliki pengaruh secara siginifikan. Pada sumber variasi latar belakang prodi, nilai $\mathrm{F}$ hasil perhitungan pada taraf signifikansi 5 persen menunjukkan $\mathrm{F}=34,051 \geq 3,119=\mathrm{F}(\alpha=0,05: 2,75)$. Perhitungan ini menunjukkan bahwa nilai $\mathrm{F}$ data jauh lebih besar dari nilai $\mathrm{F}$ yang diperoleh dari tabel untuk derajat kebebasan, $\mathrm{dk}=2$ dan 75. Atas dasar hasil ini, maka hipotesis nol untuk efek utama ini ditolak dan berarti 
bahwa secara signifikan nilai rata-rata sikap pemaafan yang diperoleh mahasiswa prodi JS lebih tinggi daripada nilai rata-rata yang diperoleh mahasiswa prodi AS, dan MU. Analisis data tersebut sekaligus mendukung hipotesis penelitian sebagaimana dikemukakan sebelumnya, yaitu bahwa terdapat perbedaan sikap pemaafan antara mahasiswa prodi JS dengan mahasiswa prodi yang lain (AS \& MU). Ini juga mengindikasikan bahwa latar belakang prodi memiliki pengaruh yang signifikan pada variasi tingkat sikap pemaafan mahasiswa.

Selanjutnya hasil analisis dalam tabel di atas juga memperlihatkan bahwa pada sumber variasi jenis kelamin, nilai $\mathrm{F}$ hasil perhitungan pada taraf signifikansi 5 persen menunjukkan $\mathrm{F}=45,342 \geq$ $3,968=\mathrm{F}(\alpha=0,05: 1,75)$. Perhitungan ini menunjukkan bahwa nilai $\mathrm{F}$ data jauh lebih besar dari nilai $\mathrm{F}$ yang diperoleh dari tabel untuk derajat kebebasan, $\mathrm{dk}=1 \mathrm{dan} 75$. Atas dasar hasil ini, maka hipotesis nol untuk efek utama ini juga ditolak dan berarti bahwa secara signifikan nilai ratarata sikap pemaafan yang diperoleh mahasiswa laki-laki lebih tinggi daripada nilai rata-rata yang diperoleh mahasiswa perempuan. Hasil analisis data tersebut mendukung hipotesis penelitian sebagaimana dikemukakan sebelumnya, bahwa terdapat perbedaan sikap pemaafan antara mahasiswa dengan jenis kelamin laki-laki dengan mahasiswa berjenis kelamin perempuan (mahasiswa dengan jenis kelamin laki-laki memiliki potensi sikap pemaafan yang lebih tinggi dibanding mahasiswa dengan jenis kelamin perempuan). Dengan kata lain penelitian ini memiliki kesimpulan bahwa jenis kelamin memiliki pengaruh yang signifikan pada variasi tingkat sikap pemaafan mahasiswa. 
Adapun untuk efek interaktif kedua faktor, hasil analisis sebagaimana dalam tabel di atas menunjukkan hasil tidak signifikan. Hasil perhitungan tersebut menunjukkan bahwa nilai $F$ hasil perhitungan terhadap data sikap pemaafan yang bersumber pada interaksi kedua faktor lebih kecil dari nilai $\mathrm{F}$ yang diperoleh dari tabel untuk derajat kebebasan, $\mathrm{dk}=1$ dan 75 pada taraf signifikansi 5 persen. Nilai-nilai tersebut adalah $\mathrm{F}=-12,530<3,119=\mathrm{F}(\alpha=0,05: 1,75)$. Nilai $\mathrm{F}$ dalam perhitungan tersebut lebih kecil dari nilai tabel, sehingga hipotesis nol diterima. Hal ini berarti bahwa tidak ada perbedaan signifikan antara nilai rata-rata sikap pemaafan yang diperoleh mahasiswa dalam sel-sel/kelompok interaksi. Hasil ini mengindikasikan bahwa hipotesis penelitian yang menyatakan bahwa "Ada pengaruh interaktif antara latar belakang prodi dengan jenis kelamin terhadap sikap pemaafan" tidak didukung oleh data secara empiris. Dengan kata lain, bahwa latar belakang prodi dan jenis kelamin secara simultan tidak berpengaruh terhadap perbedaan sikap pemaafan mahasiswa.

Hasil uji hipotesis sebagaimana diuraikan di atas menegaskan bahwa secara independen latar belakang prodi dan jenis kelamin berpengaruh secara signifikan terhadap sikap pemaafan mahasiswa. Perbedaan kedua faktor tersebut secara konsisten juga tercermin dalam perbedaan kecenderungan sikap pemaafan mahasiswa. Akan tetapi, kombinasi atau interaksi antara kedua faktor tidak berpengaruh secara signifikan terhadap sikap pemaafan. Tidak adanya pengaruh interaksi ini menunjukkan bahwa pengaruh salah satu faktor sikap pemaafan mahasiswa tetap konsisten meskipun faktor lain dikontrol. Dengan kata lain, apapun jenis kelaminnya, mahasiswa yang belajar dalam prodi JS 
memiliki kecenderungan sikap pemaafan yang lebih tinggi dari pada mereka yang belajar pada prodi yang lain (AS, dan MU). Demikian juga, dengan latar belakang prodi apapun, mahasiswa laki-laki cenderung memiliki sikap pemaafan lebih tinggi dibanding mahasiswa perempuan.

\section{Pembahasan}

Berdasarkan hasil analisis terhadap data dalam penelitian ini, baik secara deskriptif maupun uji hipotesis, maka dapat disampaikan beberapa analisis sebagai berikut; Pertama, pengaruh prodi terhadap sikap pemaafan ditunjukkan oleh kenyataan bahwa mahasiswa yang belajar di prodi JS memiliki tingkat memaafkan yang lebih tinggi dibanding mahasiswa dari prodi yang lain. Temuan ini memberikan petunjuk bahwa masing-masing prodi memberi stimulan yang berbeda terhadap tumbuh dan berkembangnya sikap pemaafan pada mahasiswa. Prodi JS sebagai satu-satunya prodi di Fakultas Syari'ah yang mengkhususkan diri pada bidang hukum Pidana Islam dianggap memiliki potensi stimulasi yang tinggi bagi mahasiswa JS untuk menumbuhkan dan mengembangkan sikap pemaafan mereka. Keberadaan mata kuliah fikih jinayah yang dipelajari lebih intensif pada prodi ini dimungkinkan menjadi faktor yang menstimulasi tingginya tingkat pemaafan.

Perspektif teori pendidikan, tujuan pendidikan selain sebagai transfer of knowledge juga merupakan sarana untuk pembentukan karakter (character building). Secara teoritis proses pembelajaran secara sistematis bertujuan untuk mengkonstruksi perubahan pada diri seseorang. Artinya proses pembelajaran secara teoritis akan berpengaruh terhadap sikap 
seseorang. Hal ini sebagaimana pendapat Baharuddin, bahwa belajar adalah setiap perubahan tingkah laku yang relatif tetap dan terjadi sebagai hasil latihan atau pengalaman. ${ }^{35}$ Dalam konteks pendidikan Islam, hakikat pendidikan adalah dalam rangka menciptakan manusia sempurna secara intelektual, sosial, dan spiritual sesuai yang dimiliki oleh Nabi Muhammad sebagai contoh paripurna (al-matsal al-kämil).

Pemaafan juga menjadi salah satu solusi atas berbagai permasalahan dan konflik yang terjadi antar manusia, sehingga terbangun kembali keharmonisan hubungan antara mereka. Bahkan dalam kasus pidana (jarimah) sekalipun, Al-Qur'an memperkenalkan mekanisme pemaafan sebagai sebuah solusi permanen atas permasalahan jarimah qisas-diyat. Surat al-Baqarah ayat 178-179 menjelaskan bahwa al-Qur'an merespons praktik qisas dengan menginkulturasikan nilai baru, yaitu: keadilan, kesetaraan, moralitas, dan pertanggungjawaban individu. Paradigma qisas dalam al-Qur'an menekankan pada prinsip rehabilitatif, yaitu mereformasi moralitas masyarakat, khususnya pelaku tindak pembunuhan. Hal ini dapat dilihat dengan adanya alternatif hukuman yang ditawarkan al-Qur'an, yaitu membayar diyat, memberi maaf, dan menyelesaikannya dengan perdamaian. Alternatif hukuman ini bertujuan untuk menyelesaikan konflik dengan mengedepankan toleransi dan menghilangkan rasa dendam. Hukuman qisas bukan semata-mata untuk melakukan social

35 Baharuddin \& Esa Nur Wahyuni, Teori Belajar dan Pembelajaran (Yogyakarta: Ar-Ruzz Media, 2009), hal. 14. 
control dengan membalas kejahatan, tetapi untuk social engineering yaitu menjaga kelangsungan kehidupan manusia. ${ }^{36}$

Kedua, perbedaan jenis kelamin berpengaruh terhadap potensi memaafkan pada seseorang. Selain merupakan ciri-ciri yang bersifat fisik, jenis kelamin juga menandai sebuah perbedaan karakter dan emosi. Secara stereotipe perempuan dianggap lebih emosional, sebaliknya lakilaki dianggap lebih rasional. Perbedaan kualitas emosional inilah yang diyakini berimplikasi pada besar dan kecilnya potensi untuk dapat melupakan rasa sakit yang dirasakan akibat perbuatan orang lain. Kaum laki-laki karena relatif lebih rasional dianggap lebih lebih mudah untuk memaafkan orang lain. Sebaliknya kaum perempuan dengan lebih besarnya tingkat emosi dalam dirinya dianggap lebih sulit untuk memaafkan orang lain yang pernah menyakitinya. ${ }^{37}$ Sikap pemaafan ini merupakan kekuatan karakter individual, oleh karena itu lebih bersifat psikologis dibanding sosial.

Kesimpulan terakhir dari penelitian ini menyatakan bahwa pengaruh interaksi antara faktor latar belakang prodi dan jenis kelamin

36 Ali Sodiqin, Hukum Qisas, dari Tradisi Arab Menuju Hukum Islam (Yogyakarta: Tiara Wacana, 2010), hal. 192-193.

${ }^{37}$ Maksud pernyataan ini adalah adanya perbedaan antara perempuan dan laki-laki dalam dimensi expressive suppression yaitu pengaruh ketidaksadaran dalam regulasi emosi yang mengarahkan laki-laki untuk lebih menekan dan melupakan pengalaman emosi daripada perempuan. Di Indonesia, perempuan lebih diberi keleluasaan dalam mengungkapkan emosinya, sedangkan laki-laki dituntut untuk lebih memendam emosinya. Secara umum, perempuan yang larut dalam pengalaman emosi dan cenderung mengekspresikan emosinya lebih diterima dibandingkan dengan laki-laki. Lihat: Shinantya Ratnasari \& Julia Suleeman, "Perbedaan Regulasi Emosi Perempuan dan Laki-Laki di Perguruan Tinggi," Jurnal Psikologi Sosial, Vol. 15, No. 01, 2017, hal. 35-46, doi: 10.7454/jps.2017.4; Baca juga: Gregorius Bhisma Adinaya, "Penelitian Mengungkap Bahwa Perempuan Lebih Emosional Daripada Lelaki," bttps: / / nationalgeographic.grid.id/ read/13909727/penelitian-mengungkap-babwa-perempuanlebih-emosional-daripada-lelaki?page=all; 
terhadap sikap pemaafan tidak signifikan. Kesimpulan ini berarti bahwa walaupun latar belakang prodi dikontrol, pengaruh jenis kelamin terhadap sikap pemaafan mahasiswa tidak berbeda. Pada latar belakang prodi apapun, baik AS, MU, maupun JS, perbedaan jenis kelamin secara konsisten diikuti oleh perbedaan sikap pemaafan mereka. Pada ketiga prodi tersebut, mahasiswa berjenis kelamin laki-laki selalu cenderung memiliki tingkat sikap memaafkan lebih tinggi dibanding mahasiswa perempuan. Tidak adanya pengaruh interaksi tersebut juga menunjukkan bahwa walaupun jenis kelamin dikontrol, latar belakang prodi tetap menunjukkan pengaruh yang signifikan/konsisten. Apapun jenis kelaminnya mahasiswa yang belajar pada prodi JS secara konsisten memiliki kecenderungan tingkat sikap pemaafan lebih tinggi dibanding mahasiswa pada prodi lain.

Interaksi antara kedua faktor yang tidak maksimal tersebut juga menunjukkan bahwa pengaruh keduanya bersifat independen. Pengaruh salah satu faktor tidak tergantung pada faktor yang lain. Dengan demikian pemahaman terhadap latar belakang prodi dan jenis kelamin harus dilakukan secara terpisah. Meskipun demikian, karena sifat pemaafan sebagai karakter individual sangat kuat, maka di dalamnya terdapat unsur subjektivitas yang tinggi. Artinya, faktor jenis kelamin baru merupakan salah satu faktor yang mungkin memiliki kontribusi terhadap sikap pemaafan seseorang, namun pasti ada faktor-faktor lain yang secara potensial berpengaruh terhadap sikap pemaafan seseorang sebagaimana yang diungkapkan pada bagian awal penelitian ini, seperti: religiusitas, empati, penyesalan, dan tingkat pendidikan. 


\section{Penutup}

Berdasarkan analisis yang telah dilakukan maka penelitian ini menyimpulkan bahwa: Pertama, terdapat perbedaan tingkat sikap pemaafan secara signifikan antara mahasiswa prodi JS, AS, dan MU. Mahasiswa JS memiliki kecenderungan tingkat sikap pemaafan lebih tinggi dibanding mahasiswa AS dan MU. Kedua, terdapat perbedaan tingkat sikap pemaafan secara signifikan antara mahasiswa laki-laki dan perempuan. Mahasiswa laki-laki memiliki tingkat sikap pemaafan lebih tinggi dibanding mahasiswa perempuan. Ketiga, Latar belakang prodi dan jenis kelamin secara simultan tidak memiliki pengaruh terhadap sikap pemaafan. Dengan kata lain pengaruh latar belakang prodi dan jenis kelamin terhadap sikap pemaafan mahasiswa hanya bersifat independen dan parsial. Pemaafan juga menjadi salah satu solusi atas berbagai permasalahan dan konflik yang terjadi antar manusia, sehingga terbangun kembali keharmonisan hubungan antara mereka. Oleh karena itu masih diperlukan penelitian lebih lanjut dan mendalam untuk mengembangkan kajian tentang hubungan antara pemaafan dengan tingkat pendidikan.

\section{Referensi}

Adinaya, Gregorius Bhisma, "Penelitian Mengungkap Bahwa Perempuan Lebih Emosional Daripada Lelaki," bttps:// nationalgeographic.grid.id/ read/13909727/penelitianmengungkap-bahwa-perempuan-lebih-emosional-daripadalelaki?page=all;

Agustina, Hestiyani, "Perbedaan Pemaafan Ditinjau dari Jenis Kelamin," Skripsi, Malang: Universitas Muhammadiyah Malang, 2009. 
al-Badr, Abdurrazzaq bin Abdul Muhsin al-Abbad, Fikih Asmaul Husna, cet.5, Jakarta: Darus Sunnah Press, 2011.

Baharuddin \& Esa Nur Wahyuni, Teori Belajar Dan Pembelajaran. Yogyakarta: Ar-Ruzz Media, 2009.

Baroroh, Umul, "Pengaruh Tingkat Kebergamaan dan Fundamentalisme Keagamaan terhadap Persepsi tentang Kesetaraan Gender, Sikap terhadap Nikah Sirri, dan Respons pada Rencana Legislasi Nikah Sirri," Disertasi. Semarang: UIN Walisongo Semarang, 2012.

Baskin, T.W. \& R.D. Enright, "Intervention Studies on Forgiveness: A Meta-Analysis," Journal of Counseling \& Development. 82. 79-90, 2004.

Baumeister, Roy F., Julie Juola Exline, and Kristin L. Sommer. The Victim Role, Grudge Theory, and Two Dimensions of Forgiveness. In Everett L. Worthington Jr., Dimension of Forgiveness, Psychological Research and Theological Perspective, Philadelphia: The Templeton Foundation Press, 1999.

Bedell, Tina Marie, "The Role of Religiosity in Forgiveness," Dissertation, Ohio: Ohio State University, 2002.

Dayakisni, Tri, \& Hudaniah, Psikologi Sosial, Malang: UMM Press, 2009.

Faris, Abī al-Ḥusayn Aḥmad Ibn, Maqāyis al-Lughah, juz 4, t.t.p.: Ittịhād al-Kitäb al-'Arab, 2002.

Firmansyah, Furqon, Hubungan Religiusitas dan Pemaafan pada Mahasiswa Psikologi UIN Sunan Ampel yang Tinggal di Ma'had Sunan Ampel al-'Aly," Thesis, Surabaya: UIN Sunan Ampel, 2012.

Ghuzairoh, Tahmidiyah, "Perbedaaan Forgiveness Ditinjau dari Jenis Kelamin Pada Budaya Jawa," Skripsi, UIN Maulana Malik Ibrahim Malang, 2015. 
Goleman, Daniel, Emotional Intelligent, Kecerdasan Emosional; Mengapa EI Lebih Penting Daripada IQ Jakarta: Gramedia Pustaka Utama, 1999.

Hasan, Aliah B. Purwakania, "Pemaafan sebagai Variabel Moderator pada Pengaruh Religiusitas dengan Agresi Relasional di Kalangan Mahasiswa Universitas Berbasis Nilai-nilai Islam," Jurnal Al-Az̧bar Indonesia Seri Humaniora. 2. 10-20, 2013.

Hornby, Albert Sydney, Oxford Advanced Learner's Dictionary of Current English / [by] A.S. Hornby, Editor Jonathan Crowther, Oxford England: Oxford University Press, 1995.

Hurlock, Elizabeth B., Psikologi Perkembangan, Jakarta: Erlangga, 1990.

Ichsan, Sayed, "Perbedaan Pemaafan (Forgiveness) Pada Pasangan yang Bercerai di Kota Banda Aceh Ditinjau dari Jenis Kelamin" Thesis, Universitas Syiah Kuala Banda Aceh, 2016.

Khasan, Moh, "Perspektif Islam dan Psikologi tentang Pemaafan," Jurnal Al-Taqaddum. 9. 69-94, 2017.

Kurniati, Ni Made Taganing, "Studi Meta-Analisis Hubungan Religiusitas dan Pemaafan," Jurnal Ilmu Psikologi. 5. 76-90, 2011.

L.Y. Thompson, Snyder, C.R., Hoffman, L., Michael, S.T., Rasmussen, H.N., Billings, L.S., Heinze, L., Neufeld, J.E., Shorey, H.S., Roberts, J.C., \& Robert, D.E., "Dispositional Fogiveness of Self, Other, and Situation," Journal of Social and Personality Psychology. 73, 2005.

Mc.Cullough, M.E, Fincham, F.D and Tsang, J. Forgiveness, "Forbearance and Time: The Temporal Unfolding of Transgression-Related Interpersonal Motivations," Journal of Personality and Social Psychology. 84, 2003. 
McCullough, M.E, Worthington, E.L, and Rachal, K.C., "Interpersonal Forgiving in Close Relationships," Journal of Personality and Social Psychology. 73, 1997.

McCullough, Michael E., "Forgiveness as Human Strength: Theory, Measurement, and Links to Well-Being," Journal of Social and Clinical Psychology. 19, 2000.

Nashori, Fuad, Pemaafan Mahasiswa Etnis Jawa Ditinjan dari Nilai Budaya Jawa, Sifat Kepribadian, dan Faktor Demografis, Yogyakarta: DPPM-UII, 2012.

Nashori, Fuad, "Pemaafan pada Etnis Jawa Ditinjau dari Faktor Demografi” Jurnal Psikologika. 18. 119-128, 2013.

Nashori, Fuad, "Meningkatkan Kualitas Hidup dengan Pemaafan", Unisia, Vol. 33 No. 75 Juli 2011.

Poerwadarminta, W.J.S., Kamus Umum Bahasa Indonesia. Jakarta: Balai Pustaka, 2010.

Prihantini, Anisa, "Hubungan Religiusitas dan Kecerdasan Emosi dengan Perilaku Pemaafan pada Wanita Janda," Skripsi, Yogyakarta: UIN Sunan Kalijaga, 2016.

Ratnasari, Shinantya \& Julia Suleeman, "Perbedaan Regulasi Emosi Perempuan dan Laki-Laki di Perguruan Tinggi," Jurnal Psikologi Sosial, Vol. 15, No. 01, 2017, doi: 10.7454/jps.2017.4

Safaria \& Saputra, Manajemen Emosi, Jakarta: Bumi Aksara, 2009.

Skinner, Sue Walrond, "The Function and Role of Forgiveness in Working with Couples and Families: Clearing the Ground" Journal of Family Therapy. 20. 3-19, 1998.

Shihab, M. Quraish, Tafsir Tematik atas Pelbagai Persoalan Umat, Bandung: Mizan, 2007.

Sodiqin, Ali, Hukum Qisas, dari Tradisi Arab Menuju Hukum Islam, Yogyakarta: Tiara Wacana, 2010. 
Sumiati, Ilsan, \& Stefanus Soejanto Sandjaja, Hubungan antara Pemaafan dan Kematangan Diri pada Remaja Akhir, Jurnal Noetic Psychology. 3. 144-162, 2013.

Wade, S.B., Gorsuch, R., \& Rosik, C.H., "The development of a scale to measure forgiveness," Journal of Psychology and Christianity, 1990.

Webster's New World College Dictionary, Third Edition, New York: A Simon and Schuster Mc.Millan Company, 1996.

Yulitasari, Eluzia, "Hubungan religiusitas dan pemaafan pada pelayan gereja Isa al-Masih Pati," Skripsi, Semarang: Unika Soegijapranata, 2016. 